\title{
Mouse Taste Buds Use Serotonin as a Neurotransmitter
}

\author{
Yi-Jen Huang, ${ }^{1}$ Yutaka Maruyama, ${ }^{1}$ Kuo-Shyan Lu, ${ }^{1}$ Elizabeth Pereira, ${ }^{1}$ Ilya Plonsky, ${ }^{1}$ John E. Baur, ${ }^{1}$ Dianqing Wu, ${ }^{1}$ and \\ Stephen D. Roper ${ }^{1,2}$ \\ ${ }^{1}$ Department of Physiology and Biophysics and 2 Program in Neuroscience, University of Miami School of Medicine, Miami, Florida 33136
}

Synapses between gustatory receptor cells and primary sensory afferent fibers transmit the output signal from taste buds to the CNS. Several transmitter candidates have been proposed for these synapses, including serotonin (5-HT), glutamate, acetylcholine, ATP, peptides, and others, but, to date, none has been unambiguously identified. We used Chinese hamster ovary cells stably expressing $5-\mathrm{HT}_{2 \mathrm{C}}$ receptors as biodetectors to monitor 5-HT release from taste buds. When taste buds were depolarized with $\mathrm{KCl}$ or stimulated with bitter, sweet, or sour (acid) tastants, serotonin was released. $\mathrm{KCl}$ - and acid-induced 5-HT release, but not release attributable to sweet or bitter stimulation, required $\mathrm{Ca}^{2+}$ influx. In contrast, 5-HT release evoked by sweet and bitter stimulation seemed to be triggered by intracellular $\mathrm{Ca}^{2+}$ release. These experiments strongly implicate serotonin as a taste bud neurotransmitter and reveal unexpected transmitter release mechanisms.

Key words: biosensors; taste; serotonin; transmitters; calcium imaging; phospholipase $\mathrm{C} \beta 2$

\section{Introduction}

It has long been known that serotonin stimulates gustatory sensory afferent fibers when that biogenic amine is injected into the tongue near taste buds (Esakov et al., 1983), suggesting that 5-HT may be a taste bud neurotransmitter (for review, see Nagai et al., 1996). A number of findings have subsequently supported that notion. For example, serotonin is present in a subset of taste cells in a wide variety of species (Whitear, 1989; Delay et al., 1993; Kim and Roper, 1995). In mammals, many of the taste cells that synapse with nerve fibers are serotonergic: they take up the serotonin precursor 5-hydroxytryptophan (5-HTP) and are immunopositive for 5-HT (Takeda, 1977; Kim and Roper, 1995; Yee et al., 2001). Reverse transcription-PCR data indicate that $5-\mathrm{HT}_{1 \mathrm{~A}}$ and $5-\mathrm{HT}_{3}$ receptors are expressed in taste tissue, with $5-\mathrm{HT}_{1 \mathrm{~A}}$ receptors found in taste cells and 5- $\mathrm{HT}_{3}$ receptors found in sensory primary afferent fibers (Kaya et al., 2004). Finally, there is indirect evidence from autoradiographic studies showing that, when depolarized, amphibian taste cells release serotonin (Nagai et al., 1998). However, despite these findings, one of the most important of the canonical criteria for identifying synaptic neurotransmitters, namely detecting its release from stimulated synapses,

\footnotetext{
Received Oct. 27, 2004; revised Nov. 30, 2004; accepted Nov. 30, 2004.

This work was supported by National Institutes of Health-National Institute on Deafness and Other Communication Disorders Grant DC006077 (S.D.R.). We thank Dr. K. Berg for the generous gift of $\mathrm{CHO} / 5-\mathrm{HT}_{2 \mathrm{C}}$ cells.

Correspondence should be addressed to Dr. Stephen Roper, Department of Physiology and Biophysics, University of Miami School of Medicine, 1600 Northwest 10th Avenue, Miami, FL 33136. E-mail: roper@miami.edu.

Y.-J. Huang's present address: Department of Anatomy, College of Medicine, Kaohsiung Medical University, Kaohsiung 807, Taiwan.

K.-S. Lu's present address: Department of Anatomy and Cell Biology, College of Medicine, National Taiwan University, Taipei 100, Taiwan.

I. Plonsky's present address: The Institute for Information Transmission Problems, Russian Academy of Science, 19 Bolshoy Karetny per., Moscow 101447, Russia.

J. E. Baur's present address: Department of Chemistry, 214 Julian Hall, Illinois State University, Normal, IL 61790.

D. Wu's present address: Department of Genetics and Developmental Biology, University of Connecticut Health Center, 263 Farmington Avenue, Farmington, С 06030.

D0I:10.1523/JNEUROSCI.4446-04.2005

Copyright $\odot 2005$ Society for Neuroscience $\quad$ 0270-6474/05/250843-05\$15.00/0
}

has yet to be unambiguously established in taste buds for serotonin or for any other candidate. We used novel biosensor cells to detect the secretion of transmitter candidates from taste buds and report that taste stimulation elicits serotonin release.

Parts of this work have been published previously in abstract form (Huang et al., 2005).

\section{Materials and Methods}

Biosensor cells. Chinese hamster ovary $(\mathrm{CHO})$ cells expressing $5-\mathrm{HT}_{2 \mathrm{C}}$ receptors (Berg et al., 1994) were seeded into 35-mm-diameter culture dishes. To produce biosensors, cells were suspended in HBSS containing $0.125 \%$ trypsin and collected in a $15 \mathrm{ml}$ centrifuge tube after terminating the reaction with $2 \%$ FBS. Dispersed CHO cells were loaded with $4 \mu \mathrm{M}$ fura-2 AM for $1 \mathrm{~h}$ at room temperature. An aliquot of fura-2-loaded cells was transferred to a recording chamber and viewed with an Olympus Optical (Tokyo, Japan) IX70 inverted microscope to test their responses to bath-applied 5-HT, KCl, cycloheximide, acetic acid, and saccharin. Sequential fluorescence microscopic images were recorded with a longpass emission filter ( $\geq 510 \mathrm{~nm}$ ) with the cells excited at $340 \mathrm{~nm}$, followed by $380 \mathrm{~nm}$, and the ratios were calculated with Imaging Workbench version 5 software (INDEC Biosystems, Mountain View, CA) (data shown are these ratios, labeled $F_{340} / F_{380}$ in Figures 1-3).

Isolated taste buds. We removed the lingual epithelium containing taste papillae from the tongues of adult C57BL/6J female mice by injecting a mixture of $1 \mathrm{mg} / \mathrm{ml}$ collagenase A (Roche Diagnostics, Indianapolis, IN), $2.5 \mathrm{mg} / \mathrm{ml}$ dispase II (Roche Diagnostics), and $1 \mathrm{mg} / \mathrm{ml}$ trypsin inhibitor (Sigma, St. Louis, MO) directly under the epithelium surrounding taste papillae. The peeled epithelium was bathed in Ca-free solution for $30 \mathrm{~min}$ at room temperature, and isolated taste buds were drawn into firepolished glass micropipettes with gentle suction. Taste buds were transferred to a shallow recording chamber that had a glass coverslip base. The coverslip was coated with Cell-Tak (BD Biosciences, San Jose, CA) to hold the taste buds firmly in place. Taste buds were perfused with Tyrode's solution (in mM): $140 \mathrm{NaCl}, 5 \mathrm{KCl}, 2 \mathrm{CaCl}_{2}, 1 \mathrm{MgCl}_{2}, 10$ HEPES, 10 glucose, 10 Na-pyruvate, and $5 \mathrm{NaHCO}_{3}$, pH 7.4 (310-320 Osm).

Stimulation. Taste buds were stimulated by bath perfusion of $\mathrm{KCl}$ ( 50 mM; substituted equimolar for $\mathrm{NaCl})$, cycloheximide $(10-100 \mu \mathrm{M})$, sodium saccharin $(2-20 \mathrm{~mm})$, aspartame $(1-10 \mathrm{~mm})$, and acetic acid 
$(8 \mathrm{~mm})$. All of the stimuli were made up in Tyrode's solution and applied at $\mathrm{pH}$ 7.2, except for acetic acid, which was applied at $\mathrm{pH} 5$.

Immunohistochemistry. Isolated taste buds were fixed for $10 \mathrm{~min}$ in $4 \%$ paraformaldehyde in PBS. Taste buds were then rinsed three times in PBS and incubated for $2 \mathrm{~h}$ in PBS containing $0.3 \%$ Triton X-100, 2\% normal donkey serum, and $2 \%$ bovine serum albumin. Taste buds were incubated with rabbit polyclonal anti-serotonin antibodies (1:1000; catalog \#S5545; Sigma) for 60-90 min at room temperature. Thereafter, taste buds were washed three times in PBS, incubated for $1 \mathrm{~h}$ in Alexa Fluor 594-conjugated donkey anti-rabbit secondary antibodies (1:500; Molecular Probes, Eugene, OR), and then washed again three times in PBS.

\section{Results}

We produced biosensor cells for detecting serotonin by using CHO cells transfected with high-affinity 5-HT receptors. CHO-K1 cells stably expressing $5-\mathrm{HT}_{2 \mathrm{C}}$ receptors (Berg et al., 1994) were suspended in buffer and loaded with the $\mathrm{Ca}^{2+}$. sensitive dye fura-2. Fura-loaded $\mathrm{CHO} / 5-\mathrm{HT}_{2 \mathrm{C}}$ cells responded robustly to bath-applied serotonin. The threshold for activation was $\sim 3 \mathrm{nM}$, and $\mathrm{EC}_{50}$ was $9 \mathrm{~nm}$ (Fig. $1 A$ ). This compares with the $\mathrm{EC}_{50}$ values of 15 and $29 \mathrm{~nm}$ reported previously for $\mathrm{Ca}^{2+}$ mobilization in fura-loaded $\mathrm{CHO}$ cells transiently transfected with 5- $\mathrm{HT}_{2 \mathrm{C}}$ receptors (Akiyoshi et al., 1995, 1996). Biosensor cells respond to ATP (endogenous purinoreceptors), as well as to serotonin. Thus, we used mianserin, a $5-\mathrm{HT}_{2}$ receptor antagonist, to differentiate responses to 5-HT from activation of endogenous (ATP) receptors (see below). Responses to 5-HT were reversibly blocked by $10 \mathrm{nM}$ mianserin, but ATP responses were unaffected (Fig. $1 B$ ). Fura-loaded $\mathrm{CHO} / 5-\mathrm{HT}_{2 \mathrm{C}}$ cells did not respond with $\mathrm{Ca}^{2+}$ signals to carbachol or glutamate up to $1 \mathrm{~mm}$ (data not shown). Furthermore, $\mathrm{CHO} / 5-\mathrm{HT}_{2 \mathrm{C}}$ cells did not respond to depolarization with bath-applied $\mathrm{KCl}(50 \mathrm{~mm}$; substituted for $\mathrm{NaCl}$ ) nor to bath-applied taste stimuli-cycloheximide (100 $\mu \mathrm{M})$, an aversive (bitter) taste compound for rodents, or saccharin $(20 \mathrm{~mm})$, a preferred (sweet) taste compound (Fig. 1C). The biosensor cells also did not respond to acetic acid stimulation (in humans, sour; $8 \mathrm{~mm}, \mathrm{pH}$ 5; data not shown). Last, $\mathrm{CHO} / 5-\mathrm{HT}_{2 \mathrm{C}}$ cells maintained their responses to bath-applied serotonin even if $\mathrm{Ca}^{2+}$ in the medium was replaced with $\mathrm{Mg}^{2+}$, consistent with the coupling of 5- $\mathrm{HT}_{2 \mathrm{C}}$ receptors to intracellular $\mathrm{Ca}^{2+}$ release mechanisms (Fig. 1C). In short, $\mathrm{CHO} / 5-\mathrm{HT}_{2 \mathrm{C}}$ cells were sensitive and reliable biosensors for serotonin, serotonergic responses could be differentiated from those produced by activating endogenous purinergic receptors by applying mianserin, and biosensor cells did not respond to taste stimuli or depolarization with $\mathrm{KCl}$.

Subsequently, we isolated taste buds from vallate papillae of the mouse tongue. Serotonergic cells could be observed readily by immunostaining taste buds isolated for recording (Fig. 2A), verifying that their 5-HT content was maintained throughout the isolation procedure. Using fura-2-loaded taste buds, we verified that, as shown previously (Richter et al., 2004), 50\% of taste bud cells are depolarized by bath-applied $\mathrm{KCl}(50 \mathrm{~mm})$. Also, as shown previously (Bernhardt et al., 1996), cells in isolated taste buds responded to bath-applied bitter tastants (here, $10-100 \mu \mathrm{M}$ cycloheximide) and saccharin (2-20 mM). Parenthetically, different taste cells responded to cycloheximide, saccharin, or $\mathrm{KCl}$ depolarization, but we did not investigate this systematically. Others have shown in more intact preparations of taste buds that many taste cells are responsive to two or more taste qualities (Gilbertson et al., 2001; Caicedo et al., 2002). Taste buds did not respond to low concentrations of bath-applied serotonin (3-10 nM).

We transferred an aliquot of suspended, fura-2-loaded $\mathrm{CHO} /$ $5-\mathrm{HT}_{2 \mathrm{C}}$ cells into a chamber containing freshly isolated mouse taste buds adhering to the glass coverslip base of the chamber. A
A

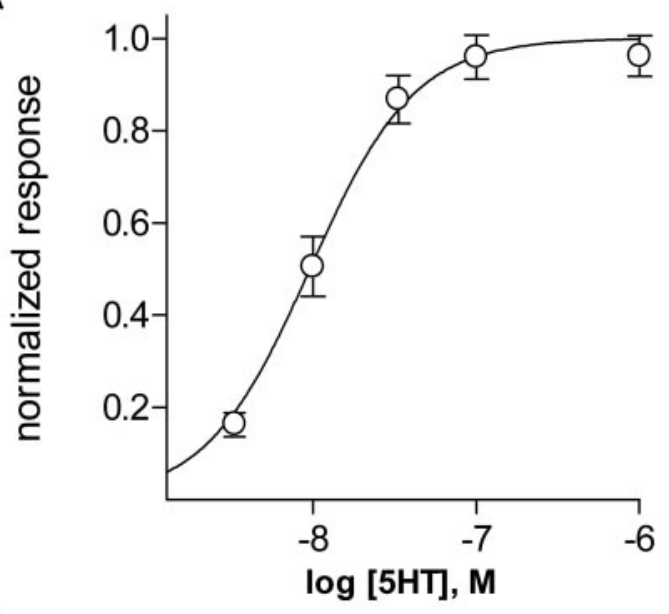

B
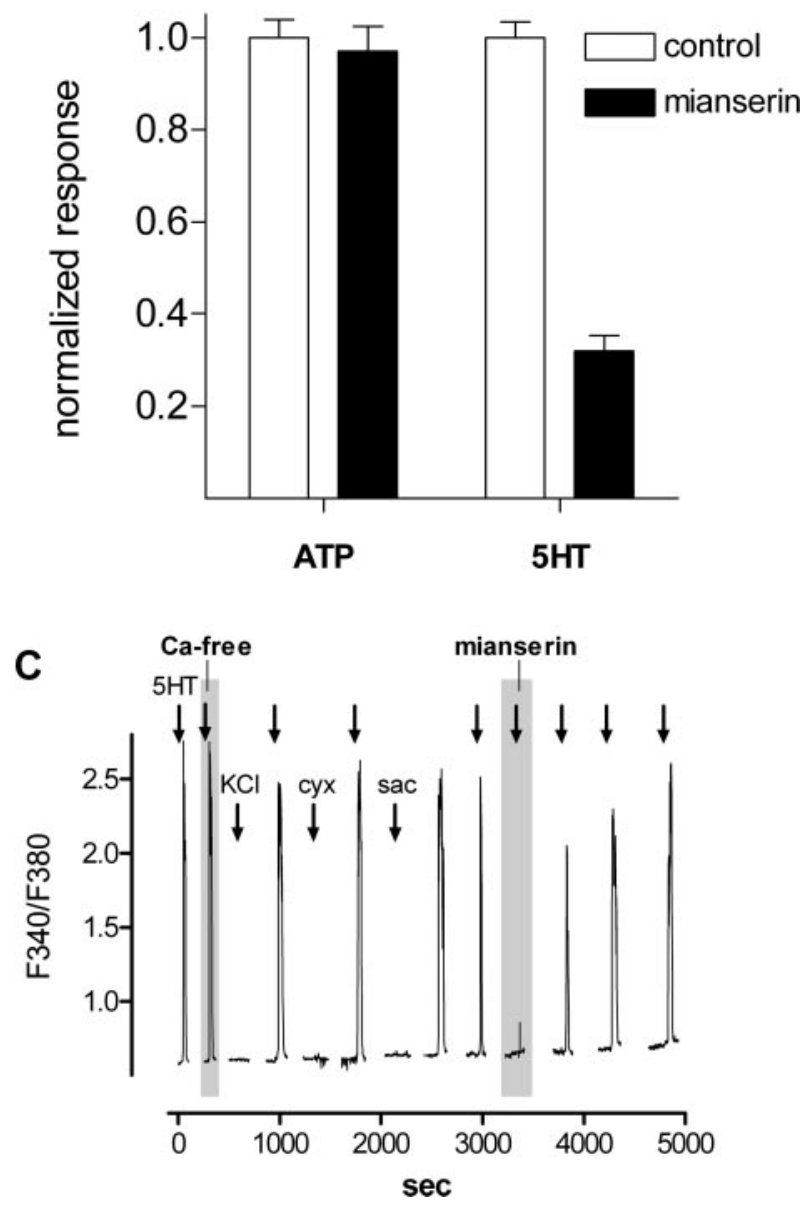

Figure 1. $\mathrm{Ca}^{2+}$ mobilization in $\mathrm{CHO} / 5-\mathrm{HT}_{2 \mathrm{C}}$ cells elicited by serotonin and ATP. Cells were loaded with fura-2, and responses were measured as the ratio of emission to fluorescent excitation at $340-$ $380 \mathrm{~nm}$. $A$, Concentration-response relationships for 5 -HT. Open circles indicate the mean \pm SEM (31 cells). $B, \mathrm{CHO}_{2}-\mathrm{HT}_{2 \mathrm{C}}$ cell responses evoked by $3 \mu \mathrm{m}$ ATP and $3 \mathrm{~nm}$ 5-HT. Open columns, Control responses. Filled columns, Effects of mianserin (10 nm), a 5- $\mathrm{HT}_{2 \mathrm{C}}$ antagonist. Mianserin does not affect $\mathrm{Ca}^{2+}$ mobilization in response to ATP but reduces responses t0 5 -HT. Data are from a different experiment from that shown in A. ATP and 5-HT responses were measured in parallel, and responses are normalized to each agonist separately. $\mathrm{C}, \mathrm{Ca}^{2+}$ mobilization in $\mathrm{CHO} / 5-\mathrm{HT}_{2 \mathrm{C}}$ cells is elicited by repeated applications of 5-HT but not by tastants or depolarization with $\mathrm{KCl}$. Sequential responses elicited by $10 \mathrm{~nm} 5-\mathrm{HT}$ in the presence of $2 \mathrm{~mm} \mathrm{Ca}^{2+}$ and in nominally $0 \mathrm{~mm} \mathrm{Ca}^{2+}$ (shaded area labeled "Ca-free"), $50 \mathrm{~mm} \mathrm{KCl,} 100 \mu \mathrm{m}$ cycloheximide, and $20 \mathrm{~mm}$ saccharin and recovery of 5-HT responses after brief application of 10 nm mianserin (shaded area labeled "mianserin"). In this and subsequent figures, fura-2 excitation was extinguished between stimulus episodes to reduce phototoxicity and photobleaching, resulting in discontinuities in the traces. cyx, Cycloheximide; sac, saccharin. 
A

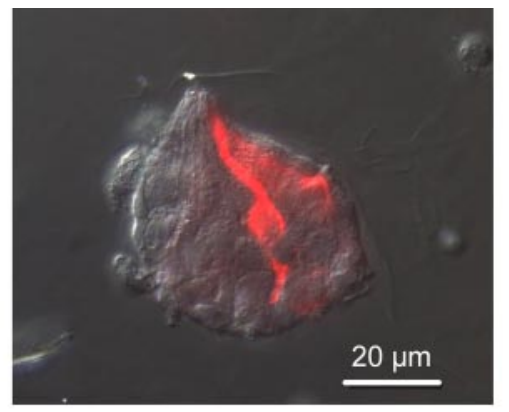

B
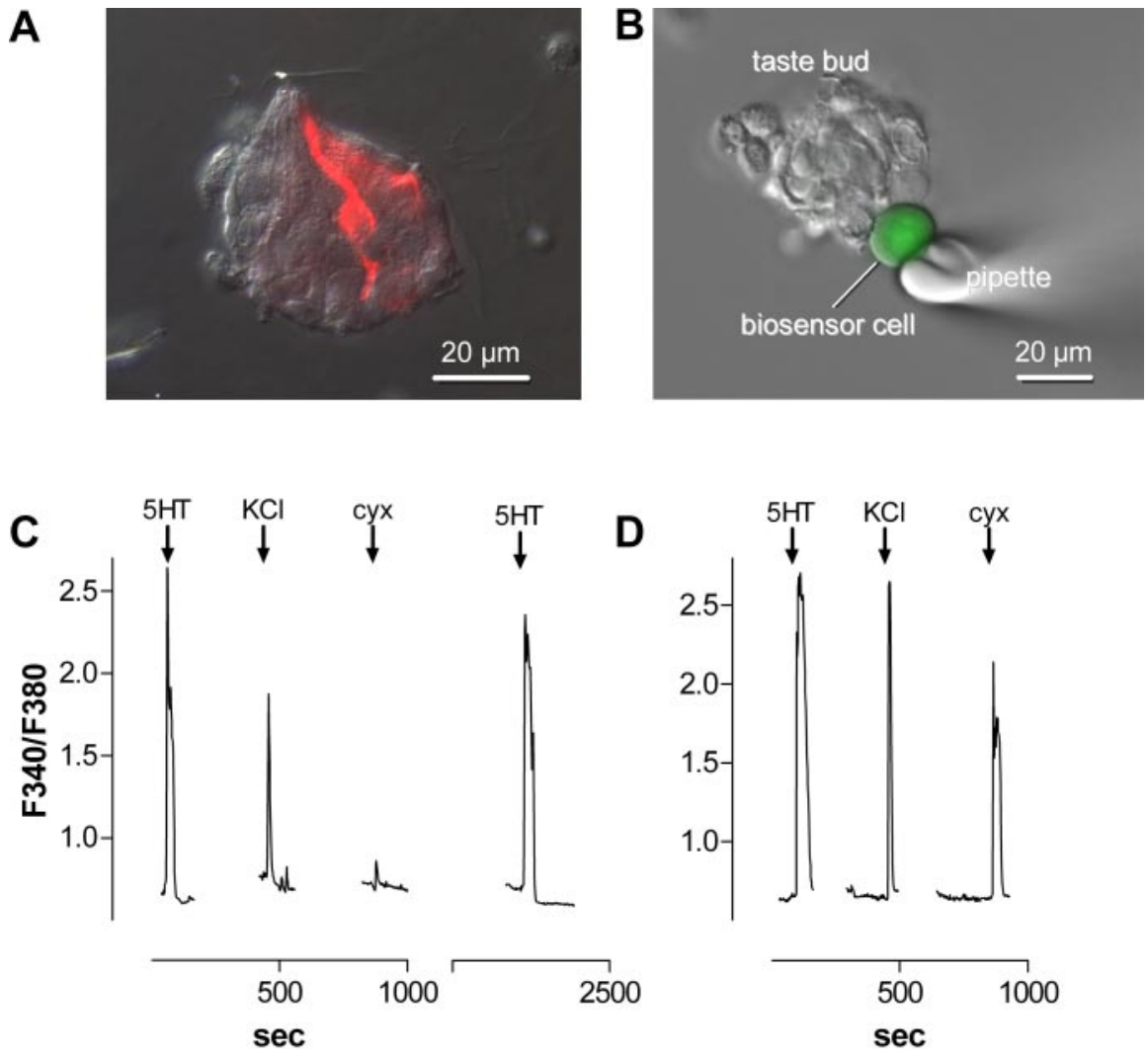

E

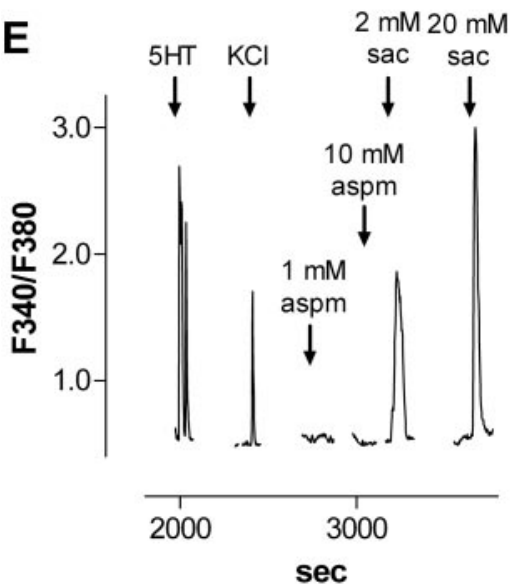

$\mathbf{F}$

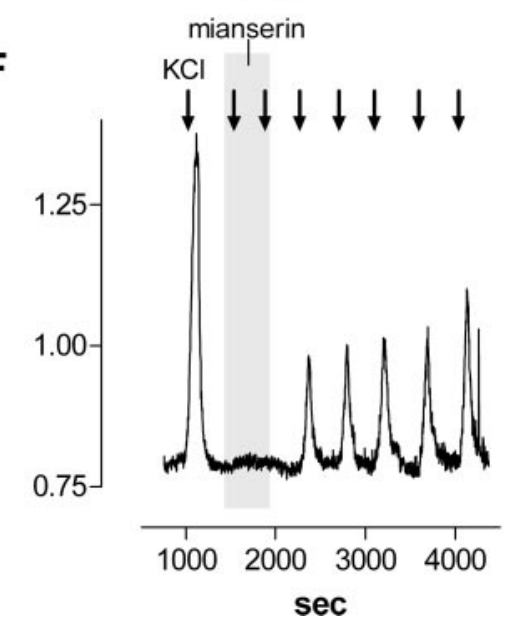

Figure 2. $\mathrm{CHO} / 5-\mathrm{HT}_{2 \mathrm{C}}$ cells are biosensors for detecting serotonin release from isolated taste buds. $A$, Micrograph of a fixed, isolated taste bud immunostained for serotonin. Two immunopositive taste cells (red) are visible in this plane of focus. A Nomarski differential interference contrast image was merged with an immunofluorescent micrograph for this micrograph. $B$, Micrograph of a fura-2-loaded (green) biosensor cell abutted against an isolated taste bud in a living preparation. A Nomarski differential interference contrast image and a fluorescence microscopy image were merged. C, Ca ${ }^{2+}$ mobilization in a biosensor cell positioned against a taste bud, as in B. The biosensor cell was initially stimulated with 3 nм 5 -HT ( $\downarrow$ ) to verify its sensitivity, followed by $50 \mathrm{~mm} \mathrm{KCl}$ to depolarize taste cells and $100 \mu \mathrm{m}$ cycloheximide (cyx). D, A procedure similar to that in C was conducted on a taste bud preparation that had been pretreated with $500 \mu \mathrm{m} 5$-hydroxytryptophan to elevate the serotonin concentration in taste cells. Responses evoked by depolarization and taste stimulation are enhanced by this procedure. E, Saccharin (sac), but not aspartame (aspm), evoked serotonin release from taste buds. F, Mianserin (1 nm; shaded area) reversibly reduced the biosensor responses evoked by depolarizing taste buds repeatedly with $50 \mathrm{~mm} \mathrm{KCl}(\downarrow)$.

biosensor cell was drawn onto a fire-polished glass micropipette with gentle suction and maneuvered to an isolated taste bud (Fig. $2 B$ ). Mere physical contact between the biosensor cell and the taste bud did not elicit a response, nor did bath perfusion with buffer alone. However, perfusing the chamber with $\mathrm{KCl}$, cycloheximide, saccharin, or acetic acid evoked rapid and repeatable biosensor responses (Figs. $2 C-E, 3 A-C$ ). When a first attempt to record a response was unsuccessful, repositioning the biosensor sometimes revealed signals evoked by stimuli. To date, we have obtained successful biosensor recordings from 31 of 105 taste buds when testing $\mathrm{KCl}$ depolarization. Eight of those 31 taste buds also yielded biosensor responses to stimulation with cycloheximide or saccharin (one of these taste buds produced a biosensor response to cycloheximide and saccharin alike). In a separate series of experiments, 6 of 13 taste buds showed responses to acetic-acid stimulation; these same taste buds also showed biosensor responses to $\mathrm{KCl}$ depolarization. Responses were abolished if the biosensor cell was withdrawn a few micrometers from the isolated taste bud and returned when the biosensor was repositioned to the same location. These tests identified the taste bud as the source of the release and suggested that release sites were spatially restricted within the taste bud, consistent with the presence of only a limited number of serotonergic cells (Fig. 2A).

Biosensor responses were generally small but were enhanced significantly by incubating lingual epithelium for $30 \mathrm{~min}$ with $500 \mu \mathrm{M} 5$-HTP, the immediate precursor to 5-HT, before isolating taste buds (Fig. 2, compare $C, D$ ). Furthermore, responses to stimuli were reversibly blocked by $1 \mathrm{~nm}$ mianserin (Fig. $2 \mathrm{~F}$ shows data for $\mathrm{KCl}$ depolarization). Because mianserin specifically blocked serotonergic responses (Fig. 1) and because 5-HTP is a precursor for serotonin, these observations verified that the biosensor cell was detecting 5-HT released from taste buds and not responding to other compounds, such as ATP, had they been secreted. We also stimulated isolated mouse taste buds with aspartame, an artificial sweetener for humans but one that is generally not preferred by and does not evoke taste nerve responses in mice (Inoue et al., 2001). Figure $2 E$ shows that aspartame, even at 10 $\mathrm{mM}$, is ineffective, validating further that the biosensor responses are produced by taste stimulation per se.

Last, we tested whether serotonin release was $\mathrm{Ca}^{2+}$ dependent. Magnesium (3 $\mathrm{mM})$ was substituted for $\mathrm{Ca}^{2+}(2 \mathrm{mM})$ in the bath, and taste buds were stimulated with $\mathrm{KCl}$ and tastants, as above. In the case of $\mathrm{KCl}$ depolarization and acid stimulation, replacing $\mathrm{Ca}^{2+}$ with $\mathrm{Mg}^{2+}$ rapidly and reversibly blocked or significantly reduced serotonin release (Fig. $3 A, B$ ), consistent with influx of $\mathrm{Ca}^{2+}$ through depolarization-gated Ca channels and consistent with known synaptic mechanisms. Surprisingly, serotonin release elicited by cycloheximide (Fig. 3A) or saccharin (Fig. $3 B$ ) was not affected by replacing $\mathrm{Ca}^{2+}$ with $\mathrm{Mg}^{2+}$. Bitter and nonsugar sweeteners stimulate intracellular $\mathrm{Ca}^{2+}$ release in 
taste cells via a signaling cascade involving phospholipase $\mathrm{C} \beta 2$ (PLC $\beta 2)$ and $\mathrm{IP}_{3}$ (Bernhardt et al., 1996; Spielman et al., 1996). Thus, a likely source of $\mathrm{Ca}^{2+}$ for transmitter release elicited by these compounds was an intracellular store. Because pharmacological interventions designed to test this notion would also affect the $\mathrm{CHO} / 5-\mathrm{HT}_{2 \mathrm{C}}$ biosensor, we used a different approach to answer this question. We isolated taste buds from PLC $\beta 2$ null mutant mice (Jiang et al., 1997) and tested their ability to release serotonin after stimulation. Taste buds from PLC $\beta 2$ null mice responded to bath-applied $\mathrm{KCl}$, showing a normal release of serotonin (Fig. 3D), as above. However, we were unable to detect serotonin release evoked by cycloheximide or saccharin from taste buds of the mutant mice, consistent with the source of $\mathrm{Ca}^{2+}$ for transmitter release being intracellular stores (via a PLC $\beta 2$ signaling cascade). Specifically, we obtained successful recordings from 16 of 56 taste buds from the knock-out mice when testing $\mathrm{KCl}$ depolarization; none of these taste buds responded to cycloheximide or saccharin.

\section{Discussion}

This report presents data that indicate that serotonin is one of the neurotransmitters released by taste cells in response to gustatory stimulation. Furthermore, the results suggest that certain stimuli evoke neurotransmitter release in response to $\mathrm{Ca}^{2+}$ derived from intracellular stores. The postsynaptic target(s) for the serotonin remain to be determined. Serotonin may excite primary sensory afferent fibers, as proposed long ago by a number of investigators (Takeda, 1977; Esakov et al., 1983) (for review, see Nagai et al., 1996). Serotonin may also function as a paracrine hormone and act on cells within the taste bud, as discussed by Fujita et al. (1988), Ewald and Roper (1994), and more recently by Kaya et al. (2004). Our experiments were not designed to distinguish between these possibilities, both of which remain open questions.

The approach we used to detect neurotransmitters, a sensitive biosensor, has been used previously. For example, catfish horizontal cells were used to detect glutamate release from goldfish retinal bipolar cells (Tachibana and Okada, 1991) and from lizard cone photoreceptors (Savchenko et al., 1997). Myocytes have been pressed against Chinese hamster ovary fibroblasts to detect acetylcholine release (Morimoto et al., 1995). Researchers used human embryonic kidney 293 (HEK293) cells expressing the E-prostanoid receptor EP1 to monitor the release of prostaglandin E2 from macula densa cells isolated from rabbit kidneys (PetiPeterdi et al., 2003). That group subsequently used cultured mouse mesangial cells to detect ATP released from macula densa cells (Komlosi et al., 2004). We are not aware of any group using biosensors to identify serotonin as a transmitter.

The incidence of successful serotonin release sites (e.g., for $\mathrm{KCl}$ stimulation, 31 of 105 taste buds) is low, presumably attributable to the relatively few numbers of serotonergic cells present in taste buds (Fig. 2), to the necessity that the taste bud was transmitter release. HAc, Acetic acid.
B
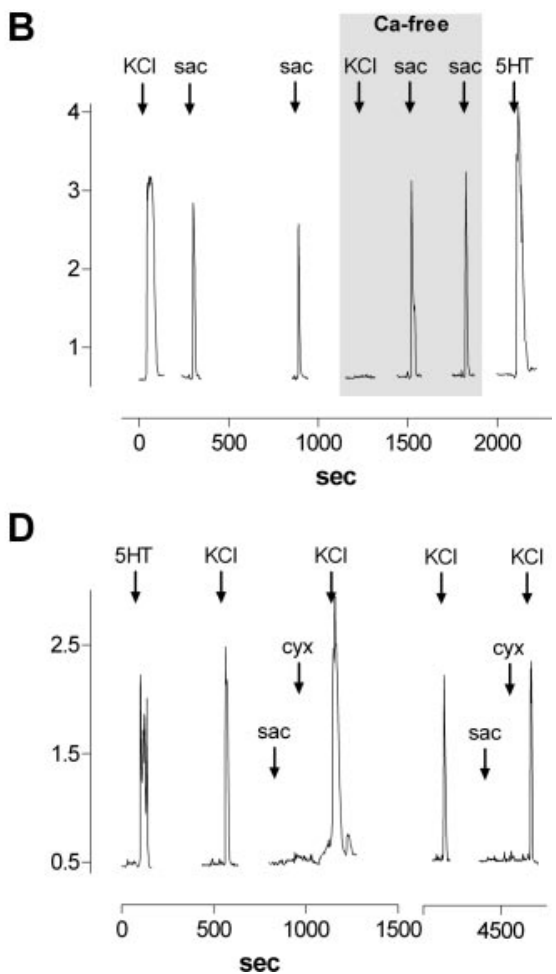

Figure 3. Serotonin release from taste buds depends on $\mathrm{Ca}^{2+}$ influx for acid stimulation and $\mathrm{KCl}$ depolarization but not for taste bud after stimulation with $50 \mathrm{~mm} \mathrm{KCl} \mathrm{(} \downarrow$ ) or $100 \mu \mathrm{m}$ cycloheximide (cyx; $\downarrow)$. The biosensor was tested for sensitivity at the for $3 \mathrm{~mm} \mathrm{Mg} 2+$. recordings. $\mathrm{KCl}$ depolarization evoked serotonin release, but neither $20 \mathrm{~mm}$ saccharin nor $100 \mu \mathrm{m}$ cycloheximide stimulated

oriented such that serotonergic cells were positioned at the periphery and accessible to the biosensor, and to the requirement that the biosensor had to be placed quite near to a release site. Movement of the biosensor of only a few micrometers from a successful recording site would immediately abolish the responses, emphasizing the spatial sensitivity for placing the biosensor. It is possible that surveying a more extensive panel of taste stimuli and alternative depolarizing agents would increase the incidence of recording serotonin release sites.

Neurotransmitter release from taste cells seems to depend on two sources of $\mathrm{Ca}^{2+}$. For depolarizing stimuli (here, $\mathrm{KCl}$ and acid taste stimulation) (cf. Richter et al., 2003, 2004), $\mathrm{Ca}^{2+}$ influx was necessary and sufficient to stimulate serotonin release. For bitter and sweet tastants (cycloheximide and saccharin) that stimulated G-protein-coupled receptors, transmitter release persisted in the absence of extracellular $\mathrm{Ca}^{2+}$ (substituted with $\mathrm{Mg}^{2+}$ ). There are three possible explanations for this. (1) Replacing $\mathrm{Ca}^{2+}$ with $\mathrm{Mg}^{2+}$ in the bath did not totally eliminate $\mathrm{Ca}^{2+}$, and residual $\mathrm{Ca}^{2+}$ in the chamber, albeit low, might have sufficed to elicit transmitter release (Piccolino and Pignatelli, 1996). (2) Transmitter release in taste buds is truly $\mathrm{Ca}^{2+}$ independent, and, for example, is mediated by $\mathrm{Na}$-dependent transporters, such as that which occurs at certain retinal synapses (Schwartz, 2002). (3) Transmitter release evoked by tastants is triggered by $\mathrm{Ca}^{2+}$ from internal stores. Our finding that exchanging $\mathrm{Ca}^{2+}$ for $\mathrm{Mg}^{2+}$ totally abolished depolarization-evoked release is inconsistent 
with the first possibility. There is a report of the serotonin transporter SET in taste buds, but it was not believed to be related to transporter-mediated transmitter release (Ren et al., 1999). Instead, our findings with the PLC $\beta 2$ knock-out mice support the last explanation. Previous studies have reported that $\mathrm{Ca}^{2+} \mathrm{de}-$ rived from intracellular stores can modulate (Emptage et al., 2001; Yang et al., 2001; Simkus and Stricker, 2002; Galante and Marty, 2003) (but see Carter et al., 2002) or possibly elicit (Llano et al., 2000) neurotransmitter release at synapses. Taste bud cells may represent an excellent model for studying transmitter release triggered by $\mathrm{Ca}^{2+}$ from intracellular stores.

Note added in proof. Hayashi et al. (2004) recently reported generating biosensor cells for ATP using pheochromocytoma 12 or HEK293 cells expressing P2X2 purinergic receptors.

\section{References}

Akiyoshi J, Nishizono A, Yamada K, Nagayama H, Mifune K, Fujii I (1995) Rapid desensitization of serotonin 5-HT2C receptor-stimulated intracellular calcium mobilization in $\mathrm{CHO}$ cells transfected with cloned human 5-HT2C receptors. J Neurochem 64:2473-2479.

Akiyoshi J, Isogawa K, Yamada K, Nagayama H, Fujii I (1996) Effects of antidepressants on intracellular $\mathrm{Ca}^{2+}$ mobilization in $\mathrm{CHO}$ cells transfected with the human 5-HT2C receptors. Biol Psychiatry 39:1000-1008.

Berg KA, Clarke WP, Sailstad C, Saltzman A, Maayani S (1994) Signal transduction differences between 5-hydroxytryptamine type $2 \mathrm{~A}$ and type $2 \mathrm{C}$ receptor systems. Mol Pharmacol 46:477-484.

Bernhardt SJ, Naim M, Zehavi U, Lindemann B (1996) Changes in IP3 and cytosolic $\mathrm{Ca}^{2+}$ in response to sugars and non-sugar sweeteners in transduction of sweet taste in the rat. J Physiol (Lond) 490:325-336.

Caicedo A, Kim KN, Roper SD (2002) Individual mouse taste cells respond to multiple chemical stimuli. J Physiol (Lond) 544:501-509.

Carter AG, Vogt KE, Foster KA, Regehr WG (2002) Assessing the role of calcium-induced calcium release in short-term presynaptic plasticity at excitatory central synapses. J Neurosci 22:21-28.

Delay RJ, Taylor R, Roper SD (1993) Merkel-like basal cells in Necturus taste buds contain serotonin. J Comp Neurol 335:606-613.

Emptage NJ, Reid CA, Fine A (2001) Calcium stores in hippocampal synaptic boutons mediate short-term plasticity, store-operated $\mathrm{Ca}^{2+}$ entry, and spontaneous transmitter release. Neuron 29:197-208.

Esakov AI, Golubtsov KV, Solov'eva NA (1983) Significance of serotonin in the activity of the taste receptor apparatus of the frog Rana temporaria (in Russian). Zh Evol Biokhim Fiziol 19:62-67.

Ewald DA, Roper S (1994) Bidirectional synaptic transmission in Necturus taste buds. J Neurosci 14:3791-3801.

Fujita T, Kanno T, Kobayashi S (1988) The paraneuron. Tokyo: Springer.

Galante M, Marty A (2003) Presynaptic ryanodine-sensitive calcium stores contribute to evoked neurotransmitter release at the basket cell-Purkinje cell synapse. J Neurosci 23:11229-11234.

Gilbertson TA, Boughter Jr JD, Zhang H, Smith DV (2001) Distribution of gustatory sensitivities in rat taste cells: whole-cell responses to apical chemical stimulation. J Neurosci 21:4931-4941.

Hayashi S, Hazama A, Dutta AK, Sabirov RZ, Okada Y (2004) Detecting ATP release by a biosensor method. Sci STKE 258:p114.

Huang YJ, Maruyama Y, Lu KS, Pereira E, Roper SD (2005) Mouse taste buds release serotonin in response to taste stimuli. Chem Senses, in press.

Inoue M, McCaughey SA, Bachmanov AA, Beauchamp GK (2001) Whole nerve chorda tympani responses to sweeteners in C57BL/6ByJ and 129P3/J mice. Chem Senses 26:915-923.

Jiang H, Kuang Y, Wu Y, Xie W, Simon MI, Wu D (1997) Roles of phos- pholipase C beta2 in chemoattractant-elicited responses. Proc Natl Acad Sci USA 94:7971-7975.

Kaya N, Shen T, Lu SG, Zhao FL, Herness S (2004) A paracrine signaling role for serotonin in rat taste buds: expression and localization of serotonin receptor subtypes. Am J Physiol Regul Integr Comp Physiol 286:R649-R658.

Kim DJ, Roper SD (1995) Localization of serotonin in taste buds: a comparative study in four vertebrates. J Comp Neurol 353:364-370.

Komlosi P, Peti-Peterdi J, Fuson AL, Fintha A, Rosivall L, Bell PD (2004) Macula densa basolateral ATP release is regulated by luminal $[\mathrm{NaCl}]$ and dietary salt intake. Am J Physiol Renal Physiol 286:F1054-F1058.

Llano I, Gonzalez J, Caputo C, Lai FA, Blayney LM, Tan YP, Marty A (2000) Presynaptic calcium stores underlie large-amplitude miniature IPSCs and spontaneous calcium transients. Nat Neurosci 3:1256-1265.

Morimoto T, Popov S, Buckley KM, Poo MM (1995) Calcium-dependent transmitter secretion from fibroblasts: modulation by synaptotagmin I. Neuron 15:689-696.

Nagai T, Kim DJ, Delay RJ, Roper SD (1996) Neuromodulation of transduction and signal processing in the end organs of taste. Chem Senses 21:353-365.

Nagai T, Delay RJ, Welton J, Roper SD (1998) Uptake and release of neurotransmitter candidates, $\left[{ }^{3} \mathrm{H}\right]$ serotonin, $\left[{ }^{3} \mathrm{H}\right]$ glutamate, and $\left[{ }^{3} \mathrm{H}\right]$ gammaaminobutyric acid, in taste buds of the mudpuppy, Necturus maculosus. J Comp Neurol 392:199-208.

Peti-Peterdi J, Komlosi P, Fuson AL, Guan Y, Schneider A, Qi Z, Redha R, Rosivall L, Breyer MD, Bell PD (2003) Luminal $\mathrm{NaCl}$ delivery regulates basolateral PGE2 release from macula densa cells. J Clin Invest 112:76-82.

Piccolino M, Pignatelli A (1996) Calcium-independent synaptic transmission: artifact or fact? Trends Neurosci 19:120-125.

Ren Y, Shimada K, Shirai Y, Fujimiya M, Saito N (1999) Immunocytochemical localization of serotonin and serotonin transporter (SET) in taste buds of rat. Brain Res Mol Brain Res 74:221-224.

Richter TA, Caicedo A, Roper SD (2003) Sour taste stimuli evoke $\mathrm{Ca}^{2+}$ and pH responses in mouse taste cells. J Physiol (Lond) 547:475-483.

Richter TA, Dvoryanchikov GA, Chaudhari N, Roper SD (2004) Acidsensitive two-pore domain potassium (K2P) channels in mouse taste buds. J Neurophysiol 92:1928-1936.

Savchenko A, Barnes S, Kramer RH (1997) Cyclic-nucleotide-gated channels mediate synaptic feedback by nitric oxide. Nature 390:694-698.

Schwartz EA (2002) Transport-mediated synapses in the retina. Physiol Rev 82:875-891.

Simkus CR, Stricker C (2002) The contribution of intracellular calcium stores to mEPSCs recorded in layer II neurones of rat barrel cortex. J Physiol (Lond) 545:521-535.

Spielman AI, Nagai H, Sunavala G, Dasso M, Breer H, Boekhoff I, Huque T, Whitney G, Brand JG (1996) Rapid kinetics of second messenger production in bitter taste. Am J Physiol 270:C926-C931.

Tachibana M, Okada T (1991) Release of endogenous excitatory amino acids from ON-type bipolar cells isolated from the goldfish retina. J Neurosci 11:2199-2208.

Takeda M (1977) ) Uptake of 5-hydroxytryptophan by gustatory cells in the mouse taste bud. Arch Histol Jpn 40:243-250.

Whitear M (1989) Merkel cells in lower vertebrates. Arch Histol Cytol $52: 415-422$.

Yang F, He X, Feng L, Mizuno K, Liu XW, Russell J, Xiong WC, Lu B (2001) PI-3 kinase and IP3 are both necessary and sufficient to mediate NT3induced synaptic potentiation. Nat Neurosci 4:19-28.

Yee CL, Yang R, Bottger B, Finger TE, Kinnamon JC (2001) “Type III” cells of rat taste buds: immunohistochemical and ultrastructural studies of neuron-specific enolase, protein gene product 9.5, and serotonin. J Comp Neurol 440:97-108. 